\title{
RHODIUM CARBENE COMPLEXES AS HYDROSILYLATION CATALYSTS
}

By: J. E. Hill and Terrence A. Nile

J.E. Hill and T.A. Nile*, "Rhodium Carbene Complexes as Hydrosilylation Catalysts," J. Organometal. Chem., 137(3), 293 (1977).

Made available courtesy of Elsevier: http://www.elsevier.com/

*** Reprinted with permission. No further reproduction is authorized without written permission from Elsevier. This version of the document is not the version of record. Figures and/or pictures may be missing from this format of the document. $* * *$

\section{Summary:}

The catalytic activity of various rhodium carbene complexes has been investigated. These complexes are active for the hydrosilylation of a wide variety of unsaturated organic molecules such as olefins, acetylenes and dienes. Their activity is comparable to other rhodium(I) complexes previously used as hydrosilylation catalysts. The yield of products is found to vary with catalyst, silane and organic substrate.

\section{Article:}

\section{Introduction}

The recent reports that transition metal carbene complexes are active in the catalysis of the olefin metathesis reaction [1,2], has focused attention on the catalytic activity of this type of complex. We have utilized the complexes I- IV, prepared from the electron-rich olefins (for example eqn. 1), or prepared by three fragment oxidative addition reactions (for example eqn. 2), as catalysts for hydrosilylation reactions. As many rhodium compounds such as Wilkinson's compound [5], [ $\left.\mathrm{RhCl}\left(\mathrm{PPh}_{3}\right)_{3}\right]$, and chlorocarbonylbis(triphenylphosphine)rhodium(I) [6], $\left[\mathrm{RhCl}(\mathrm{CO})\left(\mathrm{PPh}_{3}\right)_{2}\right]$, are active hydrosilylation catalysts, we decided to investigate the catalytic activity of various rhodium carbene complexes, to see if the carbene ligands enhanced or modified the catalytic activity.

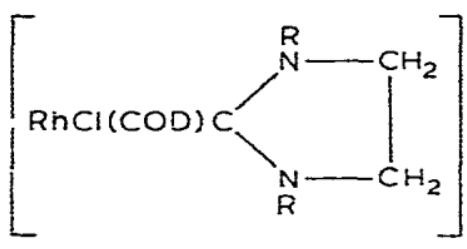

(Ia) $\mathrm{R}=\mathrm{C}_{6} \mathrm{H}_{5}$

(Ib) $\mathrm{R}=\mathrm{CH}_{3}$

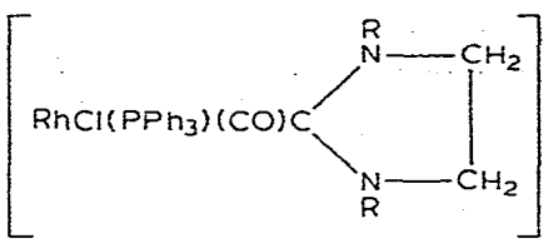

(II a) $\mathrm{R}=\mathrm{p}-\mathrm{C}_{5} \mathrm{H}_{4} \mathrm{CH}_{3}$

(口ь) $\mathrm{R}=p-\mathrm{C}_{6} \mathrm{H}_{4} \mathrm{OCH}_{3}$

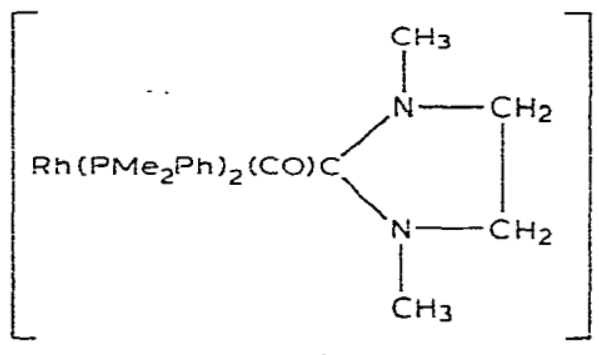

Br

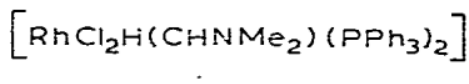

(IV)

(III)

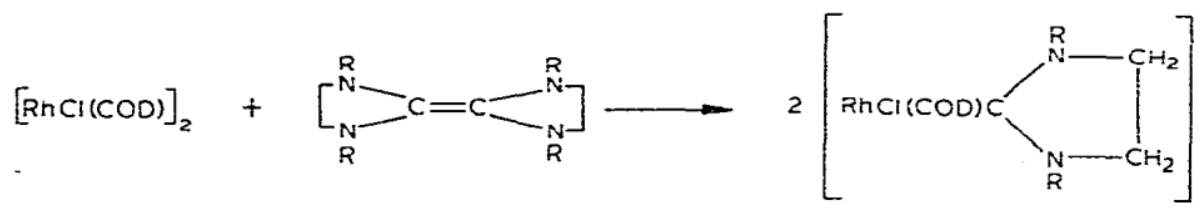

[3] (1) 


$$
\begin{aligned}
& {\left[\mathrm{RhCl}\left(\mathrm{PPh}_{3}\right)_{3}\right]+\left[\mathrm{Me}_{2} \mathrm{NCHCl}\right] \mathrm{Cl} \underset{-\mathrm{PPh}_{3}}{\stackrel{\mathrm{CHCl}_{3} \cdot 20^{\circ} \mathrm{C}}{\longrightarrow}}} \\
& {\left[\mathrm{RhCl}_{3}\left(\mathrm{CHNMe}_{2}\right)\left(\mathrm{PPh}_{3}\right)_{2}\right] \stackrel{\text { reduction }}{\longrightarrow}\left[\mathrm{RhCl}_{2} \mathrm{H}\left(\mathrm{CNMe}_{2}\right)\left(\mathrm{PPh}_{3}\right)_{2}\right] \text { [4] }}
\end{aligned}
$$

\section{Results and discussion}

The results of the hydrosilylation of various unsaturated species are summarized in Tables 1 and 2. All reactions were carried out under standard conditions, i.e. $100^{\circ} \mathrm{C}$ for $8 \mathrm{~h}$. No attempt was made to maximize yields.

\section{Hydrosilylation of terminal olefins}

The catalytic activity of the complexes I - IV was investigated for the hydrosilylation of 1-octene by a variety of silanes (eqn. 3). The results are summarized in Table 1, together with results previously reported for other rhodium complexes.

The yields of 1-octylsilanes (V) seem sensitive to both catalyst and silane. With triethylsilane, high yields of $\mathrm{Vd}$ (approximately 95\%, with respect to silane) are obtained with complexes Ib, IIa, and IIb, whereas lower yields of $\mathrm{Vd}$ were obtained using Ia and IV as catalysts.

$$
\begin{aligned}
\mathrm{C}_{6} \mathrm{H}_{13} \mathrm{CH}=\mathrm{CH}_{2}+\mathrm{HSiX}_{3} \stackrel{100^{\circ} \mathrm{C}, 8 \mathrm{~h}}{\longrightarrow} & \mathrm{C}_{6} \mathrm{H}_{13} \mathrm{CH}_{2} \mathrm{CH}_{2} \mathrm{SiX}_{3} \\
& \text { (Va) } \mathrm{X}=\mathrm{OC}_{2} \mathrm{H}_{5} \\
& \text { (Vb) } \mathrm{X}_{3}=\left(\mathrm{CH}_{3}\right)_{2} \mathrm{C}_{6} \mathrm{H}_{5} \\
& \text { (Vc) } \mathrm{X}_{3}=\mathrm{CH}_{3}\left(\mathrm{OC}_{2} \mathrm{H}_{5}\right)_{2} \\
& \text { (Vd) } \mathrm{x}=\mathrm{C}_{2} \mathrm{H}_{5}
\end{aligned}
$$

\begin{tabular}{|c|c|c|c|c|}
\hline Catalyst ${ }^{a}$ & Oleß̃n $b$ & Silane $^{c}$ & $\begin{array}{l}\text { Conditions } \\
\left({ }^{\circ} \mathrm{C} / \mathrm{h}\right)\end{array}$ & $\begin{array}{l}\text { Yield of 1-alkyl- } \\
\text { silane } d\end{array}$ \\
\hline Ia & 1-octens & $\mathrm{HSi}(\mathrm{OEt})_{3}$ & $100 / 8$ & 92 \\
\hline Ia & 1-octene & $\mathrm{HSiMe}_{2} \mathrm{Ph}$ & $100 / 8$ & 98 \\
\hline Ia & 1-octene & - HSiMe(OEt) & $100 / 8$ & 40 \\
\hline Ia & 1-octene & HSiEt $_{3}$ & $100 / 8$ & 73 \\
\hline Ib & 1-octene & $\mathrm{HSi}(\mathrm{OEt})_{3}$ & $100 / 8$ & 62 \\
\hline Ib & 1-octene & $\mathrm{HSiMle}_{2} \mathrm{Ph}$ & $100 / 8$ & 99 \\
\hline Ib & 1-octene & $\operatorname{HSiMe}(O E t)_{2}$ & $100 / 8$ & 74 \\
\hline IIa & 1-octene & HSiEt $_{3}$ & $100 / 8$ & 96 \\
\hline IIb & 1-octene & HSiEt $_{3}$ & $100 / 8$ & 98 \\
\hline III & 1-octene & $\mathrm{HSiMe}_{2} \mathrm{Ph}$ & $100 / 8$ & 96 \\
\hline III & 1-octene & HSIMe (OEt) 2 & $100 / 8$ & 52 \\
\hline IV & 1-octene & HSiEt $_{3}$ & $100 / 8$ & 61 \\
\hline$\left[\mathrm{RhCl}\left(\mathrm{PPh}_{3}\right)_{2} \mathrm{CO}\right]$ & 1-hexene & $\mathrm{HSiCl}_{3}$ & $75 / 15$ & $90[17]$ \\
\hline$\left[\mathrm{RhCl}\left(\mathrm{PEt}_{3}\right)_{2} \mathrm{CO}\right]$ & 1-hexene & $\mathrm{HSiCl}_{3}$ & $55 / 30$ & $2[17]$ \\
\hline$\left[\mathrm{RhCl}\left(\mathrm{PPh}_{3}\right)_{3}\right]$ & 1-hexene & $\mathrm{HSiEt}_{3}$ & $60 / 140$ & $60[18]$ \\
\hline$\left[\mathrm{RhCl}\left(\mathrm{C}_{2} \mathrm{H}_{4}\right)_{2}\right]_{2}$ & 1-heptene & $\mathrm{HSiEt}_{3}$ & $85 / 2$ & $60[19]$ \\
\hline
\end{tabular}

TABLE 1

HYDROSILYLATION OF 1-OLEFINS USING RHODIUM CARBENE CATALYSTS

${ }^{a} 2 \times 10^{-2}$ mmol of catalyst. ${ }^{b} 5.3 \mathrm{mmol} 1$-octene used, ex eept for HSiMe2Ph reactions where $13 \mathrm{mmol}$ of 1-octene used. ${ }^{c}$ Quantities of silane used. HSi $\left(O E_{t}\right)_{3}, 5.4 \mathrm{mmol} ; \mathrm{HSiMe}_{2} \mathrm{Ph}, 6.5 \mathrm{mmol}$ : HSiMe(OEt) 2 . $6.2 \mathrm{mmol}$; HSiEt $3,6.3 \mathrm{mmol}^{d}$ Based on silane, calculated by quantitative GLC.

Variation in silane also causes changes in yield, dependent on catalyst. For example the yields of V, using Ia, decrease from $98 \%$ using phenyldimethylsilane, through $92 \%$ for triethoxysilane, $73 \%$ for triethylsilane to $40 \%$ for diethoxymethylsilane. A similar order of activity $\left(\mathrm{HSi}\left(\mathrm{CH}_{3}\right)_{2} \mathrm{C}_{6} \mathrm{H}_{5}>\mathrm{HSi}\left(\mathrm{OC}_{2} \mathrm{H}_{5}\right)_{3}>\mathrm{HSi}\left(\mathrm{C}_{2} 14_{5}\right)_{3}\right)$ has been found for the hydrosilylation of 1-hexene catalyzed by [ $\left.\mathrm{RhH}\left(\mathrm{PPh}_{3}\right)_{4}\right]$ [7]. However, the order of activity is different for other catalysts, for example for Ib the order of activity is $\mathrm{HSi}\left(\mathrm{C}_{2} \mathrm{H}_{5}\right)_{3} \sim \mathrm{HSi}\left(\mathrm{CH}_{3}\right)_{2} \mathrm{C}_{6} \mathrm{H}_{5}>\mathrm{HSi}$ $\left(\mathrm{OC}_{2} \mathrm{H}_{5}\right)_{3}$. This is similar to that reported for Wilkinson's compound [5]. The effect of ligands on the stability of the catalytic intermediates, proposed for Wilkinson's compound and its analogs, $\left[\mathrm{RhH}\left(\mathrm{SiX}_{3}\right) \mathrm{ClL}_{2}\right]$, was found to be a subtle balance of steric and electronic factors, dependent both on the nature of the ligands, L, and the substituents X, on silicon [8,9]. As the yield of products from hydrosilylation have been postulated [8,9] to depend inversely on the stability of this adduct, it follows that the yield of products should also be influenced by similar subtle effects in silane and ligands. Our results seem to reflect this subtle balance of effects. 
TABLE 2

\begin{tabular}{|c|c|c|c|c|}
\hline Catalyst & $\begin{array}{l}\text { a Unsaturated substrate } \\
\text { (mmol) }\end{array}$ & $\begin{array}{l}\text { Silane } \\
\text { (mmol) }\end{array}$ & Product(s) & Yield $(\%)^{b}$ \\
\hline Ia & $\begin{array}{l}\mathrm{n}-\mathrm{C}_{4} \mathrm{H}_{9} \mathrm{C} \equiv \mathrm{CH} \\
(8.7)\end{array}$ & $\begin{array}{l}\mathrm{HSiMle}_{2} \mathrm{Ph} \\
(6.5)\end{array}$ & cis- and trans $-\mathrm{C}_{4} \mathrm{H}_{9} \mathrm{CH}=\mathrm{CHSiMe}_{2} \mathrm{Ph}$ & 77 \\
\hline Ia & $\begin{array}{l}\mathrm{n}^{-} \mathrm{C}_{4} \mathrm{H}_{9} \mathrm{C}=\mathrm{CH} \\
(8.7)\end{array}$ & $\begin{array}{l}\text { HSiEt }_{3} \\
(6.3)\end{array}$ & cis- and trans- $\mathrm{C}_{4} \mathrm{H}_{9} \mathrm{CH}=\mathrm{CHSiEt}_{3}$ & 49 \\
\hline Ia & $\begin{array}{l}\mathrm{CH}_{2}=\mathrm{C}\left(\mathrm{CH}_{3}\right) \mathrm{C}\left(\mathrm{CH}_{3}\right)=\mathrm{CH}_{2} \\
(8.8)\end{array}$ & $\begin{array}{l}\mathrm{HSi}(\mathrm{OEt})_{3} \\
(5.4)\end{array}$ & $\mathrm{CH}_{2}=\mathrm{C}\left(\mathrm{CH}_{3}\right) \mathrm{CH}\left(\mathrm{CH}_{3}\right) \mathrm{CH}_{2} \mathrm{Si}(\mathrm{OE} t)_{3}$ & 24 \\
\hline Ia & 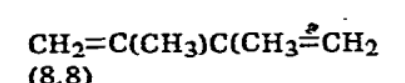 & $\begin{array}{l}\text { HSiEt }_{3} \\
(6.3)\end{array}$ & $\begin{array}{l}\left(\mathrm{CH}_{3}\right)_{2} \mathrm{C}=\mathrm{C}\left(\mathrm{CH}_{3}\right) \mathrm{CH}_{2} \mathrm{Si}\left(\mathrm{OE}_{\mathrm{i}}\right)_{3} \\
\mathrm{CH}_{2}=\mathrm{C}\left(\mathrm{CH}_{3}\right) \mathrm{CH}_{3}\left(\mathrm{CH}_{3}\right) \mathrm{CH}_{2} \mathrm{SiEt}_{3} \\
\left(\mathrm{CH}_{3}\right)_{2} \mathrm{C}=\mathrm{C}\left(\mathrm{CH}_{3}\right) \mathrm{CH}_{2} \mathrm{SiEt}_{3}\end{array}$ & $\begin{array}{l}36 \\
12 \\
86\end{array}$ \\
\hline Ib & $\begin{array}{l}\mathrm{CH}_{2}=\mathrm{C}\left(\mathrm{CH}_{3}\right) \mathrm{C}\left(\mathrm{CH}_{3}\right)=\mathrm{CH}_{2} \\
(8.8)\end{array}$ & $\begin{array}{l}\mathrm{HCi}(\mathrm{OE} t)_{3} \\
(5.4)\end{array}$ & $\begin{array}{l}\mathrm{CH}_{2}=\mathrm{C}\left(\mathrm{CH}_{3}\right) \mathrm{CH}_{\left(\mathrm{CH}_{3}\right) \mathrm{CH}_{2} \mathrm{Si}(\mathrm{OEt})_{3}} \\
\left(\mathrm{CH}_{3}\right)_{2} \mathrm{C}=\mathrm{C}\left(\mathrm{CH}_{3}\right) \mathrm{CH}_{2} \mathrm{Si}(\mathrm{OEt})_{3}\end{array}$ & $\begin{array}{l}86 \\
35 \\
35\end{array}$ \\
\hline HI & $\begin{array}{l}\mathrm{CH}_{2}=\mathrm{C}\left(\mathrm{CH}_{3}\right) \mathrm{C}\left(\mathrm{CH}_{3}\right)=\mathrm{CH}_{2} \\
(8.8)\end{array}$ & $\begin{array}{l}\text { HSi(OEt) } \\
(5.4)\end{array}$ & $\begin{array}{l}\mathrm{CH}_{2}=\mathrm{C}\left(\mathrm{CH}_{3}\right) \mathrm{CH}\left(\mathrm{CH}_{3}\right) \mathrm{CH}_{2} \mathrm{Si}(\mathrm{OEt})_{3} \\
\left(\mathrm{CH}_{3}\right)_{2} \mathrm{C}=\mathrm{C}\left(\mathrm{CH}_{3}\right) \mathrm{CH}_{2} \mathrm{Si}(\mathrm{OEt})_{3}\end{array}$ & $\begin{array}{r}4 \\
77\end{array}$ \\
\hline Ia & $\frac{\Gamma\left(\mathrm{CH}_{2}\right)_{5} \mathrm{C}}{(9.7)}=0$ & $\begin{array}{l}\mathrm{HSi}(\mathrm{OE} t)_{3} \\
(5.4)\end{array}$ & {$\left[\left(\mathrm{CH}_{2}\right)_{5} \mathrm{CHOSi}(\mathrm{OEt})_{3}\right.$} & 88 \\
\hline Ib & $\frac{\left(\mathrm{CH}_{2}\right)_{5} \mathrm{C}}{(9.7)}=0$ & $\begin{array}{l}\text { HSi(OEt) } \\
(5.4)\end{array}$ & {$\left[\left(\mathrm{CH}_{2}\right)_{5} \mathrm{CHOS}^{\mathrm{H}}(\mathrm{OEt})_{3}\right.$} & 60 \\
\hline III & $\frac{\left[\left(\mathrm{CH}_{2}\right) C\right.}{(9.7)}=0$ & $\begin{array}{l}\text { HSi(OEt) } \\
(5.4)\end{array}$ & {$\left[\left(\mathrm{CH}_{2}\right)_{5} \mathrm{CHOSi} \mathrm{OEt}\right)_{3}$} & 29 \\
\hline Ia & $\begin{array}{l}\mathrm{CH}_{2}=\mathrm{C}\left(\mathrm{CH}_{3}\right) \mathrm{C}(\mathrm{O}) \mathrm{OCH}_{3} \\
(9.5)\end{array}$ & $\begin{array}{l}\text { HSiEt } \\
\text { (6.3) }\end{array}$ & $\left(\mathrm{CH}_{3}\right)_{2} \mathrm{C}=\mathrm{C}\left(\mathrm{OCH}_{3}\right)_{\mathrm{OSiEt}_{3}}$ & 98 \\
\hline
\end{tabular}

$a_{2} \times 10^{-2} \mathrm{mmol}$ catalyst. $100^{\circ}$ for $8 \mathrm{~h}{ }^{b}$ Based on silane; calculated by quantitative GLC. containing small amounts of other products.

\section{Hydrosilylation of terminal acetylenes}

The hydrosilylation of 1-hexyne catalyzed by Ia leads to a mixture of cis-and trans-mono adducts (eqn. 4). This reaction is unusual in that transition metal-catalyzed hydrosilylation normally leads only to the trans-olefin by cis-addition. In the case of triethylsilane the ratio of cis/trans was estimated by GLC to be 80/20. Mixtures of isomers in similar ratios have been found using Wilkinsons's compound as a catalyst [10] and other rhodium catalysts [11], although the yields and ratios of isomers were found to be very sensitive to reaction conditions and ligands.

$$
\begin{aligned}
& \mathrm{r}-\mathrm{C}_{4} \mathrm{H}_{9} \mathrm{C} \equiv \mathrm{CH}+\mathrm{HSiX}_{3} \stackrel{100^{\circ} \mathrm{C}, 8 \mathrm{~h}}{\longrightarrow} \text { cis- and trans- } \mathrm{n}-\mathrm{C}_{4} \mathrm{H}_{9} \mathrm{CH}=\mathrm{CHSiX}_{3} \\
& \text { (VIa) } \mathrm{X}=\mathrm{C}_{2} \mathrm{H}_{5} \\
& \text { (VIb) } \mathrm{X}_{3}=\left(\mathrm{CH}_{3}\right)_{2} \mathrm{C}_{6} \mathrm{H}_{6}
\end{aligned}
$$

\section{Hydrosilylation of dienes}

The complexes, Ia, Ib, and III were investigated for the hydrosilylation of 2,3-dimethyl-1,3-butadiene. The results are included in Table 2 . All three catalysts gave moderate yields of $1 / 1$ diene/silane adducts and both 1,2- and 1,4-adducts were formed (eqn. 5). The proportion of each product formed being dependent on catalyst; the ratio of VIIIb/VIIb being 60/40 for Ia, 50/50 for Ib, and 95/5 for III. Wilkinson's compound is reported to give only the 1,4-adduct, cis-2-(1- triethoxysilyl)butene, when 1,3-butadiene reacts with triethoxysilane j12]. When triethylsilane reacts with 2,3-dimethyl-1,3-butadiene catalyzed by Ia, an excellent yield of 1/1 adducts $(1,4-/ 1,2$-adduct ratio, 87/13) was obtained. Small amounts $(\sim 3 \%)$ of higher boiling products were detected in these reactions.

$$
\begin{aligned}
& \mathrm{CH}_{2}=\mathrm{C}\left(\mathrm{CH}_{3}\right) \mathrm{C}\left(\mathrm{CH}_{3}\right)=\mathrm{CH}_{2}+\mathrm{HSiX}_{3} \stackrel{100^{\circ} \mathrm{C}, 8 \mathrm{~h}}{\longrightarrow} \\
& \mathrm{CH}_{2}=\mathrm{C}\left(\mathrm{CH}_{3}\right) \mathrm{CH}\left(\mathrm{CH}_{3}\right) \mathrm{CH}_{2} \mathrm{SiX}_{3}+\left(\mathrm{CH}_{3}\right)_{2} \mathrm{C}=\mathrm{C}\left(\mathrm{CH}_{3}\right) \mathrm{CH}_{2} \mathrm{SiX}_{3} \\
& \text { (VIIa) } \mathrm{X}=\mathrm{C}_{2} \mathrm{~F}_{5} \\
& \text { (VIIb) } \mathrm{x}=\mathrm{OC}_{2} \mathrm{H}_{5} \\
& \text { (VIIIa) } \mathrm{X}=\mathrm{C}_{2} \mathrm{H}_{5} \\
& \text { (VIIb) } \mathrm{x}=\mathrm{OC}_{2} \mathrm{H}_{5}
\end{aligned}
$$

\section{Hydrositylation of carbonyl compounds}

The ketone, cyclohexanone, was hydrosilylated in good yields by triethyland triethoxy-silane by catalysts Ia and $\mathrm{Ib}$, but in poor yield using III. The results are included in Table 2. The hydrosilylation of methyl methacrylate by triethylsilane, catalyzed by complex Ia, gave high yields of the 1,4-adduct (eqn. 6). A similar reaction has been reported using Wilkinson's compound [13]. 


$$
\mathrm{CH}_{2}=\mathrm{C}\left(\mathrm{CH}_{3}\right) \mathrm{C}(\mathrm{O}) \mathrm{OCH}_{3}+\mathrm{HSi}\left(\mathrm{C}_{2} \mathrm{H}_{5}\right)_{3} \stackrel{100^{\circ} \mathrm{C} .8 \mathrm{~h}}{\longrightarrow}\left(\mathrm{CH}_{3}\right)_{2} \mathrm{C}=\mathrm{C}\left[\mathrm{OSi}_{(}\left(\mathrm{C}_{2} \mathrm{H}_{5}\right)_{3}\right] \mathrm{OCH}_{3}
$$

\section{Experimental}

\section{General procedures}

All reactions were carried out under pure nitrogen, using freshly distilled, dry liquids. ${ }^{1} \mathrm{H}$ NMR spectra were recorded on a Varian Associates T60 spectrometer. IR spectra were taken with a Perkin Elmer 457 grating spectrophotometer as thin films. The GLC analysis of the reaction products was carried out on a Varian Aerograph A-700 "Autoprep" Gas Chromatograph, using a $6 \mathrm{ft}$ column of 10\% SE30 on Chromosorb G, using indane or dodecane as internal standards. Preparative GLC separations were carried out on the same machine using a $20 \mathrm{ft}$ column of $15 \%$ SE 30 on Chromosorb G. The silanes were purchased or prepared according to literature methods [14]. All the unsaturated organic compounds were commercial products, dried over molecular sieves and distilled prior to use, with the exception of 2,3-dimethy1-1,3-butadiene which was prepared by the dehydration of pinacol, by the literature method [15]. The rhodium carbene complexes were gifts from Dr. P.L. Pye, Dr. M.J. Doyle, and Dr. K. Turner, with the exception of Ia, which was synthesized by the standard method [3]. Microanalyses were performed by Integral Microanalytical Laboratories, Inc. of Raleigh, North Carolina.

The product of the hydrosilylation of methyl methacrylate by triethylsilane was identified by its ${ }^{1} \mathrm{H}$ NMR spectra [13].

\section{Hydrosilylation of 1-octene}

These reactions were carried out using the same method. The general procedure will be outlined for the hydrosilylation of 1-octene by triethoxysilane catalyzed by Ia.

Ia $(50 \mathrm{mg}, 0.1 \mathrm{mmol})$ was added to a mixture of 1-octene $(5.7 \mathrm{~g}, 50 \mathrm{mmol})$ and triethoxysilane $(4.4 \mathrm{~g}, 27 \mathrm{mmol})$ under nitrogen. The mixture was then heated with stirring to $100^{\circ} \mathrm{C}$ (oil bath temperature), and maintained at that temperature for $8 \mathrm{~h}$. The mixture was allowed to cool to room temperature and the unreacted silane and 1octene removed under reduced pressure, distillation yielded 1-(triethoxysilyl)octane $(6.2 \mathrm{~g}, 83 \%$ based on silane), b.p. $106^{\circ} \mathrm{C} / 4 \mathrm{mmHg}$. (Found: $\mathrm{C}, 61.0 ; \mathrm{H}, 12.0 . \mathrm{C}_{14} \mathrm{H}_{32} \mathrm{O}_{3} \mathrm{Si}$ calcd.: $\mathrm{C}, 60.8 ; \mathrm{H}, 11.7 \%$.) ${ }^{1} \mathrm{H}$ NMR: $\tau$ (ppm) $6.27\left(6 \mathrm{H}\right.$, quartet $\left.J 7 \mathrm{~Hz}, \mathrm{Si}-\mathrm{O}-\mathrm{CH}_{2}-\mathrm{C}\right), 8.71\left(12 \mathrm{H}\right.$, singlet, C- $\left.\left(\mathrm{CH}_{2}\right)_{6}-\mathrm{C}\right), 8.85\{9 \mathrm{H}$, triplet, $J 7 \mathrm{~Hz}$, Si-O$\left.\mathrm{C}-\mathrm{CH}_{3}\right), 8.87-9.38$ (5H broad multiplet, $\mathrm{CH}_{3}-\mathrm{C}$ and $\mathrm{C}-\mathrm{CH}_{2}-\mathrm{Si}$ ).

Also prepared using a similar method: 1-(dimethylphenylsilyl)octane, b.p. $72-75^{\circ} \mathrm{C} / 0.4 \mathrm{mmHg}$. (Found: $\mathrm{C}, 76.9$; H, 11.6. $\mathrm{C}_{16} \mathrm{H}_{28} \mathrm{Si}$ calcd.: C, 77.3; H, 11.4\%.) ${ }^{1} \mathrm{H}$ NMR: $\tau(\mathrm{ppm})$ 2.62-2.79 (5H, broad multiplet, $\left.\mathrm{Si}^{-} \mathrm{C}_{6} \mathrm{H}_{5}\right), 8.7-$ $9.4\left(17 \mathrm{H}\right.$, multiplet, $\left.\mathrm{Si}-\left(\mathrm{CH}_{2}\right),-\mathrm{CH}_{3}\right), 9.71\left(6 \mathrm{H}\right.$, singlet, $\left.\mathrm{Si}-\mathrm{CH}_{3}\right)$.

1-(Diethoxymethylsilyl)octane: b.p. $86-88^{\circ} \mathrm{C} / 2 \mathrm{mmHg}$. (Found: $\mathrm{C}, 62.7 ; \mathrm{H}, 12.3 . \mathrm{C}_{13} \mathrm{H}_{30} \mathrm{O}_{2} \mathrm{Si}$ calcd.: C, 63.3; $\mathrm{H}$, 12.3\%.) ${ }^{1} \mathrm{H}$ NMR: $\tau$ (ppm) 6.28 (4H, quartet, $\left.J 7 \mathrm{~Hz}, \mathrm{Si}-\mathrm{O}-\mathrm{CH}_{2}-\mathrm{C}\right), 8.7-9.4\left(17 \mathrm{H}\right.$, multiplet, Si- $\left(\mathrm{CH}_{2}\right) 7-\mathrm{CH}_{3}$, $8.87(6 \mathrm{H}$, triplet, $J 7 \mathrm{~Hz}$, Si-O-C-CH$), 10.06\left(3 \mathrm{H}\right.$, singlet, $\left.\mathrm{Si}-\mathrm{CH}_{3}\right)$.

\section{Hydrosilylation of cyclohexanone by triethoxysilane}

Ia (50 mg, $0.1 \mathrm{mmol})$ was added to a mixture of cyclohexanone $(3.8 \mathrm{~g}, 39 \mathrm{mmol})$ and triethoxysilane $(3.5 \mathrm{~g}, 21$ $\mathrm{mmol})$ under nitrogen. After the mixture had been heated at $100^{\circ} \mathrm{C}$ for $8 \mathrm{~h}$, unreacted silane was removed under reduced pressure at room temperature. Fractional vacuum distillation yielded cyclohexanoxytriethoxysilane (4.1 g, $75 \%$ based on silane), b.p. $100^{\circ} \mathrm{C} / 4 \mathrm{mmHg}$. (Found: $\mathrm{C}, 54.8 ; \mathrm{H}, 10.0 . \mathrm{C}_{12} \mathrm{H}_{26} \mathrm{O}_{4} \mathrm{Si}$ calcd.: C, 54.9; $\mathrm{H}, 10.0 \%$.) ${ }^{1} \mathrm{H}$ NMR: $\tau$ (ppm) 6.24 (6H, quartet, $\left.J 7 \mathrm{~Hz}, \mathrm{Si}-\mathrm{O}-\mathrm{CH}_{2}-\mathrm{C}\right), 6.32$ (1H, broad multiplet. CH-O-Si), 7.9-9.1 (10H, broad multiplet, C-( $\left.\left.\mathrm{CH}_{2}\right)_{5}\right), 8.83\left(9 \mathrm{H}\right.$, triplet, $\left.J 7 \mathrm{~Hz}, \mathrm{Si}-\mathrm{O}-\mathrm{C}-\mathrm{CH}_{3}\right)$.

\section{Hydrosilylation of 1-hexyne}

(a) By triethylsilane. To 1-hexyne (4.3 g, $52 \mathrm{mmol})$ and triethylsilane (4.4 g, $38 \mathrm{mmol})$ in a flask was added $\left(50 \mathrm{mg},\left(0.1 \mathrm{mmol}\right.\right.$ of Ia). The reaction mixture was heated to $100^{\circ} \mathrm{C}$ and maintained at that temperature for $8 \mathrm{~h}$. 
After cooling volatiles were removed under reduced pressure, and vacuum distillation yielded 1-(triethylsilyl)1-hexene (3.2 g, $42 \%$ based on silane), b.p. $58^{\circ} \mathrm{C} / 0.3 \mathrm{mmHg}$. (Found: C, 71.9; H, 13.1. $\mathrm{C}_{13} \mathrm{H}_{26} \mathrm{Si}$ calcd.: C, 72.6; $\mathrm{H}, 13.2 \%$.) GLC analysis of the product showed that it consisted of two isomers in a 80/20 ratio. Pure samples of the two isomers were obtained by preparative GLC using a Varian Aerograph 700 "Autoprep" Gas Chromatograph using a $20^{\prime}$ by $3 / 8^{\prime \prime}$ column of $15 \%$ SE 30 on Chromosorb $\mathrm{G}$ at $200^{\circ} \mathrm{C}$. The major isomer was identified as cis-1-(triethylsilyl)-1-hexene from its ${ }^{1} \mathrm{H}$ NMR: $\tau$ (ppm) $3.66(1 \mathrm{H}$, overlapping doublet of triplets; $J$ $14 \mathrm{~Hz}, J 7 \mathrm{~Hz}, \mathrm{C}-\mathrm{CH}=\mathrm{C}-\mathrm{Si}$ ), 5.67 (1H doublet, $J 14 \mathrm{~Hz}, \mathrm{C}-\mathrm{C}-\mathrm{CH}-\mathrm{Si}$ ), 7.62-8.29 (2H, borad multiplet, C=C$\mathrm{CH}_{2}-\mathrm{C}$ ), 8.29-9.87 (22H, complex pattern $\mathrm{CH}_{3} \mathrm{CH}_{2} \mathrm{CH}_{2} \mathrm{C}-\mathrm{C}=\mathrm{C}-\mathrm{Si}-\mathrm{CH}_{2} \mathrm{CH}_{3}$ ). The minor component was identified as trans-1-(triethylsilyl)-1-hexene from its ${ }^{1} \mathrm{H}$ NMR: $\tau$ (ppm) 3.90 (1H, doublet of triplets, $J 19 \mathrm{~Hz}, J^{1}$ $6 \mathrm{~Hz}, \mathrm{C}-\mathrm{CH}=\mathrm{C}-\mathrm{Si}$; literature values [16] 5.01, $\left.J 18.7 \mathrm{~Hz}, J^{1} 6 \mathrm{~Hz}\right), 4.50(1 \mathrm{H}$ doublet, $J 19 \mathrm{~Hz}, \mathrm{C}-\mathrm{C}=\mathrm{CH}-\mathrm{Si}$; literature values [16] 4.50, J 18.7 Hz), 7.61-8.14 (2H, broad multiplet, $\left.\mathrm{C}=\mathrm{C}-\mathrm{CH}_{2}-\mathrm{C}\right), 8.14-9.71(22 \mathrm{H}$, complex pattern $\left.\mathrm{CH}_{3} \mathrm{CH}_{2} \mathrm{CH}_{2} \mathrm{C}-\mathrm{C}=\mathrm{C}-\mathrm{Si}-\mathrm{CH}_{2}-\mathrm{CH}_{3}\right)$.

(b) By dimethylphenylsilane. The reaction between 1-hexyne and dimethylphenylsilane was carried out in a similar fashion yielding 1 -(dimethylphenylsilyl)hexenes. b.p. $74-75^{\circ} \mathrm{C} / 0.3 \mathrm{mmHg}$. The ${ }^{1} \mathrm{H}$ NMR spectrum indicated that the product was a mixture of isomers, as three distinct resonances for the $\mathrm{Si}-\mathrm{CH}_{3}$ protons could be distinguished ( $\tau 9.58,9.67$, and $9.71 \mathrm{ppm}$, all singlets), in the ratio of 77/18/5. However, the mixture could not be resolved or separated by GLC. The ${ }^{1} \mathrm{H}$ NMR spectrum in the region $r$ 3.4-4.7 ppm consisted of a series of peaks. Peaks assigned to cis-1-(dimethylphenylsilyl)-1-hexene, at $\tau$ (ppm) 3.63 (overlapping doublet of triplets, $J 14 \mathrm{~Hz}, J^{1} 7 \mathrm{~Hz}$ ) and 4.44 (doublet, $J 14 \mathrm{~Hz}$ ), could easily be distinguished, and accounted for the majority of the integral in this region. Thus the major product is cis-1-(dimethylphenylsilyl)-1-hexene. The minor peaks in this region are in good agreement with the literature [16] values for a mixture of trans-1-(dimethylphenylsilyl)1-hexene ( $\tau(\mathrm{ppm}) 3.90$, doublet of triplets, $J 18 \mathrm{~Hz}, J^{l} 5 \mathrm{~Hz}$, and 4.23 doublet $J 18 \mathrm{~Hz}$ ) and 2-

(dimethylphenylsilyl)-1-hexene (4.60 and 4.33), although some are obscured. From the values of the integrals for these peaks the product formed in intermediate amounts is cis-1-(dimethylphenylsilyl)-1-hexene and the minor product is 2-(dimethylphenylsilyl)-1-hexene. The ${ }^{1} \mathrm{H}$ NMR spectrum also contains the expected peaks for the $\mathrm{Si}-\mathrm{C}_{6} \mathrm{H}_{5}$ moiety $\left(\tau\right.$ 2.44-2.94 ppm) and $\mathrm{C}=\mathrm{C}-\mathrm{CH}_{2} \mathrm{CH}_{2} \mathrm{CH}_{2} \mathrm{CH}_{2} \mathrm{CH}_{3}$ protons $(\tau$ 7.74-9.39 ppm).

\section{Hydrosilylation of 2,3-dimethy1-1,3-butadiene}

(a) By triethylsilane. Ia (50 mg, $0.1 \mathrm{mmol})$ was added to a mixture of 2,3-dimethyl-1,3-butadiene (3.6 g, 44 $\mathrm{mmol}$ ) and triethylsilane (3.7 g, $32 \mathrm{mmol})$ under nitrogen. After the mixture had been heated, with stirring, for 8 $\mathrm{h}$ at $100^{\circ} \mathrm{C}$, the unreacted silane and diene were removed under reduced pressure at room temperature. Fractional vacuum distillation yielded triethylsilyl-2,3-dimethylbutenes (5.0 g, 79\% based on silane b.p. $55^{\circ} \mathrm{C} / 0.3 \mathrm{mmHg}$. (Found: $\mathrm{C}, 72.2 ; \mathrm{H}, 12.8 . \mathrm{C}_{12} \mathrm{H}_{26} \mathrm{Si}$ calcd.: $\mathrm{C}, 72.6 ; \mathrm{H}, 13.2 \%$.) GLC analysis of the product showed that it consisted of two isomers in a 87/13 ratio. Pure samples of the two isomers were separated by preparative GLC using a Varian Aerograph 700 "Autoprep" Gas Chromatograph using a 20' by 3/8" column of $15 \%$ SE 30 on Chromosorb $\mathrm{G}$ at $200^{\circ} \mathrm{C}$. The major isomer was identified as 1-(triethylsilyl)-2,3-dimethyl-2butene from its ${ }^{1} \mathrm{H}$ NMR spectrum: $\tau$ (ppm) $8.41\left(9 \mathrm{H}\right.$, singlet, $\left.\left(\mathrm{CH}_{3}\right)_{2} \mathrm{C}=\mathrm{C}\left(\mathrm{CH}_{3}\right)-\mathrm{C}\right), 8.55(2 \mathrm{H}$, singlet, $\mathrm{C}=\mathrm{C}-$ $\mathrm{CH} 2-\mathrm{Si}), 8.79-9.76\left(15 \mathrm{H}\right.$, characteristic complex pattern, $\left.\mathrm{Si}\left(\mathrm{CH}_{2}{ }^{-} \mathrm{CH}_{3}\right)_{3}\right)$. The minor isomer was identified as 4-(triethylsilyl)-2,3-dimethyl-1-butene from its ${ }^{1} \mathrm{H}$ NMR spectrum: $\tau$ (ppm) 5.46-5.59 (2H, broad multiplet, $\left.\mathrm{C}=\mathrm{CH}_{2}\right), 7.44-8.11(1 \mathrm{H}$, broad multiplet, $\mathrm{C}=\mathrm{C}-\mathrm{CH}-\mathrm{C}), 8.41\left(3 \mathrm{H}\right.$, broad singlet, $\left.\mathrm{C}=\mathrm{C}-\mathrm{CH}_{3}\right), 8.81-9.77(20 \mathrm{H}$, complex pattern $\left.\mathrm{C}=\mathrm{C}-\mathrm{C}\left(\mathrm{CH}_{3}\right)-\mathrm{CH}_{2}-\mathrm{Si}\left(\mathrm{CH}_{2} \mathrm{CH}_{3}\right)_{3}\right)$. GLC of the pot residue indicated the presence of small amounts of higher boiling products.

(b) By triethoxysilane. The hydrosilylation of 2,3-dimethyl-1,3-butadiene was carried out in a similar fashion to yield triethxoysilyl-2,3-dimethylbutenes ( $55 \%$ based on silane) b.p. $110^{\circ} \mathrm{C} / 8 \mathrm{mmHg}$. (Found: $\mathrm{C}, 57.8 ; \mathrm{H}$, 10.7. $\mathrm{C}_{12} \mathrm{H}_{26} \mathrm{O}_{3} \mathrm{Si}$ calcd.: $\mathrm{C}, 58.5 ; \mathrm{H}, 10.6 \%$.) GLC analysis of the product mixture showed that it consisted of two isomers in a 60/40 ratio. Pure samples of the isomers were isolated by preparative GLC using the same conditions as above. The major isomer was identified as 1-(triethxoysilyl)2,3-dimethyl-2-butene from its ${ }^{1} \mathrm{H}$ NMR spectrum: $\tau$ (ppm) $6.25\left(6 \mathrm{H}\right.$, quartet, $\left.J 7 \mathrm{~Hz}, \mathrm{Si}-\mathrm{O}-\mathrm{CH}_{2}-\mathrm{C}\right), 8.33\left(9 \mathrm{H}\right.$, singlet, $\left.\left(\mathrm{CH}_{3}\right)_{2} \mathrm{C}=\mathrm{C}\left(\mathrm{CH}_{3}\right)-\mathrm{C}\right), 8.43$ $\left(2 \mathrm{H}\right.$, singlet, $\left.\mathrm{C}=\mathrm{C}-\mathrm{CH}_{2}-\mathrm{Si}\right), 8.88\left(9 \mathrm{H}\right.$, triplet, $\left.\mathrm{J} 7 \mathrm{~Hz}, \mathrm{Si}-\mathrm{O}-\mathrm{C}-\mathrm{CH}_{3}\right)$. The minor isomer was identified as 4(triethoxysilyl)2,3-dimethyl-1-butene from its ${ }^{1} \mathrm{H}$ NMR spectrum: $\tau$ (ppm) 5.04-5.24 (2H, broad multiplet, 
$\left.-\mathrm{C}=\mathrm{CH}_{2}\right), 6.31\left(6 \mathrm{H}\right.$, triplet, $\left.J 7 \mathrm{~Hz}, \mathrm{Si}-\mathrm{O}-\mathrm{CH}_{2}-\mathrm{C}\right), 7.51-8.11(1 \mathrm{H}$, broad multiplet, $\mathrm{C}=\mathrm{C}-\mathrm{CH}-\mathrm{C}), 8.21-8.41(3 \mathrm{H}$, broad multiplet, $\left.\mathrm{C}=\mathrm{C}-\mathrm{C}\left(\mathrm{CH}_{3}\right)-\mathrm{Si}\right), 8.73-9.51\left(14 \mathrm{H}\right.$, complex pattern, $\left.\mathrm{C}=\mathrm{C}-\mathrm{C}\left(\mathrm{CH}_{3}\right)-\mathrm{CH}_{2} \mathrm{Si}\left(\mathrm{O}-\mathrm{C}-\mathrm{CH}_{3}\right)_{3}\right)$. GLC of the pot residue indicated the presence of small amounts of higher boiling products.

\section{References}

1 D.J. Cardin, M.J. Doyle and M.F. Leppert, Chem. Commun., (1972) 927.

2 J. McGinnis, T.J. Katz and S. Hurwitz, J. Amer. Chem. Soc., 98 (1976) 605.

3 M.J. Doyle, D. Phil. Thesis, Sussex, 1975.

4 K. Turner, D. Phil. Thesis, Sussex, 1974.

5 R.N. HasLeldine, R.V. Parish and D.J. Parry, J. Chem. Soc. A, (1969) 683.

6 F. deChartenay, J.A. Osborn and G. Wilkinson, J. Chem. Soc. A, (1968) 787.

7 H. Kona, N. Wakao, I. Ojima and Y. Nagai, Chem. Lett., (1975) 189.

8 R.N. Haszeldine, R.V. Parish and R.J. Taylor, J. Chem. Soc. Dalton Trans., (1974) 2311.

9 J. Rejhon and J. Hetflejš, Coll- Czech. Chem. Commun., 40 (1975) 3680.

10 I. Ojima, M. Kumagai and Y. Nagai, J. Organometal. Chem., 66 (1974) C14.

11 T.A. Nile, D. Phil. Theiss, Sussex, 1974.

12 J. Rejhon and J. Hetflejš, Coll. Czech. Chem. Commun., 40 (1975) 3190.

13 1. Ojima, M. Kumagai and Y. Nagai, J. Organometal. Chem., 111 (1976) 43.

14 ELF. LaPPert, T.A. Nile and S. Takahashi, J. Organometal. Chem., 72 (1974) 415 and refs. therein.

15 C.F. Allen and A. Bell, Org. Synth., Coll. Vol. 3 (1955) 312.

16 V. Chvalovskii..L Pola, V.B_ Pukhnarevich.Kopylova, E.G. Tsetlina, V.A. Pestunovich. B.A. Troimov and ELG. Voronkov, Collect. Czech. Chem. Commun., 41 (1976) 391.

17 F. deChartenay, J.A. Osborn and G. Wilkinson, J. Chem. Soc. A, (1968) 787.

18 R.N. Haszeldine, R.V. Parish and D.J. Parry, J. Chem. Soc. A, (1969) 683.

19 P. Svoboda, M. Chapka and J. Hetflejš, Coll. Czech. Chem. Commun., 37 (1972) 3059. 